AGREGAT: Jurnal Ekonomi dan Bisnis

Vol. 1, No. 1, Maret 2017

http://journal.uhamka.ac.id/index.php/agregat

p-ISSN: 2549-5658 e-ISSN: 2549-7243

DOI: $10.22236 /$ agregat_vol1/is1pp59-72

Hal 59-72

\title{
CAPITAL ADEQUACY RATIO (CAR) DAN TINGKAT SUKU BUNGA KREDIT TERHADAP PENYALURAN KREDIT DI BURSA EFEK INDONESIA
}

\author{
Fitri Malini \\ Lingkar Kajian Ekonomi Indonesia \\ Email: Fitrimalini53@yahoo.com \\ Diterima: 6 Januari 2017; Direvisi: 10 Februari 2017; Disetujui: 27 Februari 2017
}

\begin{abstract}
His study aimed to determine the effect of the Capital Adequacy Ratio (CAR), and the interest rate loans to total lending in the banking companies in the Indonesia Stock Exchange. The method used in this research is the method of explanation, the independent variables used in this study consisted of Capital Adequacy Ratio (CAR), and loan interest rates while the dependent variable is the amount of lending. The population in this study were banking companies in the Indonesia Stock Exchange, samples taken amounted to 10 (ten) companies with the research period between 2009 and 2013. Partially Capital Adequacy Ratio (CAR), significant negative effect on the amount of lending, and loan interest rates are not significant positive effect on the amount of lending. While simultaneously Capital Adequacy Ratio (CAR), and loan interest rates not significant effect on the amount of lending to the banking company in BEI 2009-2013.
\end{abstract}

Keywords: Capital Adequacy Ratio (CAR), the Interest Rate Loans, Total Lending

Abstrak

Penelitian ini bertujuan untuk mengetahui pengaruh Capital Adequacy Ratio (CAR), dan tingkat suku bunga kredit terhadap jumlah penyaluran kredit pada perusahaan perbankan di Bursa Efek Indonesia. Metode penelitian yang digunakan dalam penelitian ini adalah metode eksplanasi, variabel independen yang digunakan dalam penelitian ini terdiri dari Capital Adequacy Ratio (CAR), dan tingkat suku bunga kredit sedangkan variabel dependen adalah jumlah penyaluran kredit. Populasi dalam penelitian ini adalah perusahaan perbankan di Bursa Efek Indonesia, sampel yang diambil berjumlah 10 (sepuluh) perusahaan dengan periode penelitian antara tahun 2009 sampai dengan tahun 2013. Secara parsial Capital Adequacy Ratio (CAR), berpengaruh negatif tidak signifikan terhadap jumlah penyaluran kredit, dan tingkat suku bunga kredit berpengaruh positif tidak signifikan terhadap jumlah penyaluran kredit. Sedangkan secara simultan Capital Adequacy Ratio (CAR), dan tingkat suku bunga kredit berpengaruh tidak signifikan terhadap jumlah penyaluran kredit pada perusahaan perbankan di BEI periode 20092013.

Kata Kunci: Capital Adequacy Ratio (CAR), Tingkat Suku Bunga Kredit, Jumlah Penyaluran Kredit 


\section{PENDAHULUAN}

Perbankan memiliki peran yang sangat penting dalam perekonomian suatu negara. Semakin baik kondisi perbankan suatu negara, semakin baik pula kondisi perekonomian suatu negara. Bank memainkan peran penting dalam mekanisme pembayaran, mobilisasi, intermediasi juga alokasi modal. Fungsi tersebut dapat dilaksanakan dengan optimal, jika didukung dengan permodalan yang memadai.

Penelitian ini dilatarbelakangi oleh adanya fenomena Credit crunch pada krisis tahun 1998. Sebagaimana umumnya negara berkembang, sumber utama pembiayaan investasi di Indonesia masih didominasi oleh penyaluran kredit perbankan. Dengan demikian wajar apabila melambatnya penyaluran kredit perbankan di Indonesia setelah krisis 1998 dituding sebagai salah satu penyebab lambatnya pemulihan ekonomi Indonesia dibandingkan negara Asia lainnya yang terkena krisis (Korea Selatan dan Thailand). Meskipun kondisi makroekonomi dalam beberapa tahun terakhir relatif membaik, tercermin dari terkendalinya laju inflasi, stabilnya nilai tukar, dan turunnya suku bunga, namun kredit yang disalurkan perbankan belum cukup menjadi mesin pendorong pertumbuhan ekonomi untuk kembali pada level sebelum krisis, yang berarti bahwa fungsi intermediasi perbankan masih belum pulih atau terjadi disintermediasi perbankan.

Laporan Bank Indonesia menunjukkan bahwa belum pulihnya fungsi intermediasi perbankan antara lain disebabkan oleh masih berlangsungnya konsolidasi internal perbankan dan belum mampunya sektor riil menyerap kredit. Belum selesainya proses restrukturisasi kredit telah menimbulkan potensi meningkatnya Non Performing Loans (NPL). Sementara itu, konsolidasi internal perbankan seperti penerapan good corporate governance dan pengelolaan risiko yang baik masih merupakan proses yang dilaksanakan oleh perbankan. Semua hal tersebut sangat dicermati oleh perbankan karena pengaruhnya pada kecukupan modal perbankan atau Capital Adequacy Ratio (CAR). Di sisi lain, dalam kondisi resesi ekonomi setelah krisis, penurunan kredit perbankan dapat juga terjadi karena melemahnya permintaan kredit dari sektor swasta akibat rendahnya prospek investasi 
61 AGREGAT: Jurnal Ekonomi dan Bisnis

Vol. 1 No 1 Maret 2017

http://journal.uhamka.ac.id/index.php/agregat

DOI: 10.22236/agregat_vol1/is1pp59-72

dan belum pulihnya kondisi keuangan perusahaan.

Studi literatur menunjukkan bahwa sebab-sebab menurunnya penyaluran kredit perbankan kepada sektor swasta di Asia setelah krisis tahun 1998 masih menimbulkan perdebatan di antara para ekonom (Agenor, dkk., 2000). Sebagian ekonom berpendapat bahwa menurunnya penyaluran kredit perbankan disebabkan oleh credit crunch yang menimbulkan fenomena credit rationing sehingga terjadi penurunan penawaran kredit oleh perbankan (supply side constraint). Credit crunch atau biasa disebut quantity rationing, dimana suku bunga tidak lagi berfungsi dalam menyeimbangkan permintaan dan penawaran kredit. Credit rationing sebagai suatu kondisi dimana nasabah tertentu tidak mendapatkan kredit walaupun mereka mau membayar suku bunga pinjaman yang lebih tinggi.

Ekonom yang lain berargumentasi bahwa menurunnya penyaluran kredit perbankan lebih disebabkan oleh menurunnya permintaan terhadap kredit (demand side constraint) sebagai konsekuensi logis terjadinya kontraksi permintaan agregat (aggregate demand) dan turunnya output setelah krisis.

Menurut Agenor, dkk. (2000), penyebab menurunnya penyaluran kredit perbankan apakah berasal dari faktor permintaan kredit atau faktor penawaran kredit mempunyai implikasi penting terhadap kebijakan fiskal dan moneter. Misalkan, jika bank enggan menyalurkan kredit karena merasa naiknya risiko kegagalan yang tidak dapat diinternalisasi dengan kenaikan biaya peminjaman, maka kebijakan fiskal untuk mencoba memperbesar likuiditas guna menstimulasi permintaan agregat tidak akan efektif meningkatkan permintaan kredit. Sebaliknya, jika rendahnya penyaluran kredit disebabkan sektor usaha mengurangi permintaan terhadap kredit karena merasa lemahnya permintaan di masa datang (demand side), kebijakan fiskal ekspansi mungkin dapat mendorong permintaan agregat dan ekspansi kredit. Dari sisi kebijakan moneter, terjadinya credit crunch karena enggannya perbankan menyalurkan kredit menyebabkan kebijakan moneter yang relatif longgar tidak dapat ditransmisikan ke sektor riil melalui pemberian pinjaman. Selain itu, credit crunch juga dapat mengurangi ruang gerak bagi kebijakan moneter, karena dalam kondisi yang demikian kebijakan moneter yang menaikkan suku bunga akan memperparah 
kondisi dunia usaha.

Pemenuhan kebutuhan dana merupakan suatu hal yang tidak dapat dipisahkan dari perusahaan untuk menjalankan kegiatan operasinya. Perusahaan memiliki berbagai alternatif sumber pendanaan, baik yang berasal dari dalam maupun dari luar perusahaan. Alternatif pendanaan dari dalam perusahaan, umumnya dengan menggunakan laba yang ditahan perusahaan sedangkan alternatif pendanaan dari luar perusahaan dapat berasal dari kreditur berupa utang maupun pendanaan yang bersifat penyertaan dalam bentuk saham (equity). Pendanaan melalui mekanisme penyertaan umumnya dilakukan dengan menjual saham perusahaan kepada masyarakat atau biasa dikenal dengan go public (Sunariyah, 2011).

Dalam pasar modal tersebut usaha untuk mendapatkan dana dapat dilakukan dengan cara perusahaan mengeluarkan surat berharga atau saham yang baru dikeluarkan oleh perusahaan tersebut dijual pada pasar primer yang berupa initial public offering (IPO) atau penawaran perdana terhadap sahamnya atau dapat pula dengan cara menambah surat berharga baru jika perusahaan tersebut sudah going public. Selanjutnya surat berharga yang telah beredar diperdagangkan di pasar sekunder (Isfatun dan Hatta, 2010).

Dalam perusahaan yang go public biasanya mengalami permasalahan, yaitu fenomena underpricing. Underpricing merupakan fenomena harga rendah yang terjadi karena penawaran perdana ke publik yang secara rerata murah (Hartono, 2010). Hal ini sering diakibatkan adanya informasi yang asimetri antara perusahaan emiten dengan penjamin emisi (model baron) atau antara investor yang informed dan uninformed (model Rock) (Isfaatun dan Hatta, 2010). Fenomena underpricing merupakan fenomena yang umum di dunia, tanpa terkecuali di Indonesia. Pengamatan terhadap aktivitas IPO (initial public offering) di bursa efek Indonesia selama tahun 1990-2008 menunjukkan bahwa telah terjadi fenomena underpricing yang signifikan (Arifin, 2007).

Dalam Arifin (2007) fenomena underpricing

didokumentasikan sebelumnya oleh Ibbotson (1975). Dengan menggunakan data di pasar modal Amerika Serikat tahun 1960-1969, Ibbotson (1975) menemukan rata-rata underpricing sebesar 11,4\%. Namun pada penelitian terbaru yang dilakukan 
63 AGREGAT: Jurnal Ekonomi dan Bisnis

Vol. 1 No 1 Maret 2017

http://journal.uhamka.ac.id/index.php/agregat

DOI: 10.22236/agregat_vol1/is1pp59-72

Ibbotson et al. (1993) yang menemukan rata-rata underpricing sebesar 15,3\% pada periode tahun 1960-1992. Menurut Sembel (1996), fenomena underpricing ini tidak hanya terjadi di Amerika Serikat, tetapi juga di pasar modal di luar Amerika Serikat.

Pada tahun 2006-2012 tercatat ada 138 perusahaan melakukan IPO di Bursa Efek Indonesia, 117 perusahaan diantaranya mengalami underpricing dan 18 perusahaan lainnya mengalami overpricing atau dapat dikatakan $98.662 \%$ perusahaan yang go public sejak tahun 2006 hingga 2012 mengalami underpricing dengan rata-rata underpricing per tahun mencapai 35.904\%. Untuk lebih memudahkan, berikut ini disajikan tingkat underpricing yang terjadi pada tahun 2006-2012.

Banyak variabel yang mempengaruhi underpricing pada saat perusahaan melakukan initial public offering (IPO) di pasar modal. Mengetahui faktor yang mempengaruhi underpricing akan dapat menghindarkan perusahaan yang akan go public terhadap kerugian karena underestimate atas nilai pasar sahamnya.

Mengenai faktor-faktor yang mempengaruhi underpricing telah dilakukan banyak penelitian. Penelitian yang dilakukan oleh (Sulistio, 2005) yang menguji pengaruh akuntansi dan non akuntansi terhadap initial return sebagai proksi dari keputusan investasi pada perusahaan yang melakukan initial public offering (IPO) di Bursa Efek Jakarta. Informasi akuntansi yang digunakan dalam penelitian meliputi ukuran perusahaan, earning per share, price earning ratio dan tingkat leverage. Informasi non akuntansi yang digunakan meliputi prosentase pemegang saham lama, reputasi auditor dan reputasi underwriter. Hasil penelitian menunjukkan bahwa informasi akuntansi yang berpengaruh terhadap initial return adalah tingkat leverege, sedangkan informasi non akuntansi yang berpengaruh terhadap initial return adalah prosentase pemegang saham.

Hasil penelitian yang dilakukan oleh Yong dan Rahim (2010) di Malaysia yang meneliti faktor-faktor yang telah memberi kontribusi pada tingkat underpricing IPO di Malaysia termasuk demand (permintaan), penawaran dan pengaruh ukuran perusahaan serta jenis penawaran dan risiko untuk IPO saham syariah, yang terpisah dari saham non-syariah. Berkaitan dengan status syariah, IPO pada subsampel syariah menggunakan variabel 
yang sama dengan saham non syariah. Hasil penelitian menunjukkan bahwa initial return dari saham syariah, ukuran dan jenis penawaran berpengaruh negatif terhadap initial return dan risiko berpengaruh positif terhadap initial return sedangkan untuk saham non syariah risiko berpengaruh negatif terhadap initial return.

Menurut Bunchs and mathisen (2005) dalam bukunya yang berjudul "Competition and Efficiency in Banking” mengatakan bahwa "Capital Adequacy Ratio (CAR) is ratio measure the strength of bank's capital, and its ability to cover the risks of its undertakings and protect the interests of its depositors".

Kebijakan perkreditan harus memperhatikan keadaan keuangan saat ini seperti permodalan atau Capital Adequacy Ratio (CAR). CAR menunjukkan sejauh mana penurunan aset bank masih dapat ditutup oleh equity bank yang tersedia, semakin tinggi CAR semakin baik kondisi sebuah bank.

Menurut Brigham dan Houston (2010) dalam bukunya yang berjudul "Fundemental of Financial Management" mengatakan bahwa "interest rate is the price paid to borrow debt capital", dan yang telah dialih bahasakan oleh Ali Akbar Yulianto menyatakan pengertian suku bunga adalah "harga yang dibayarkan untuk meminjam modal utang”.

Menurut Sunariyah (2004) dalam bukunya yang berjudul "Pengantar Pengetahuan Pasar Modal” fungsi suku bunga adalah: Sebagai daya tarik bagi para penabung yang mempunyai dana lebih untuk diinvestasikan. Suku bunga dapat digunakan sebagai alat moneter dalam rangka mengendalikan penawaran dan permintaan uang yang beredar dalam suatu perekonomian. Misalnya, pemerintah mendukung pertumbuhan suatu sektor industri tertentu, apabila perusahaan-perusahaan dari industri tersebut akan meminjam dana. Maka pemerintah memberi tingkat bunga yang lebih rendah dibandingkan sektor lain.

Pemerintah dapat memanfaatkan suku bunga untuk mengontrol jumlah uang beredar. Ini berarti, pemerintah dapat mengatur sirkulasi uang dalam suatu perekonomian.

Menurut N. Gregory Mankiw (2005) dalam bukunya yang berjudul "Principles of Microeconomic" mengatakan bahwa kredit adalah:

"Credit is the trust which allows one party to provide resources to another party where that second party does not 
65 AGREGAT: Jurnal Ekonomi dan Bisnis

Vol. 1 No 1 Maret 2017

http://journal.uhamka.ac.id/index.php/agregat

DOI: 10.22236/agregat_vol1/is1pp59-72

reimburse the first party immediately (thereby generating a debt), but instead arranges either to repay or return those resources at a later date. The resources provides may be financial (e.g granting a METODE PENELITIAN

Dalam penelitian ini penentuan sampel yaitu dengan menggunakan metode purposive sampling, yaitu pemilihan sampel perusahaan selama penelitian berdasarkan kriteria tertentu. Beberapa kriteria yang ditetapkan untuk memperoleh sampel adalah sebagai berikut:

1. Perusahaan perbankan di Bursa Efek Indonesia (BEI) yang menerbitkan dan mempublikasikan laporan keuangan tahunan secara lengkap per 31 Desember dari tahun 2009 hingga tahun 2013.

2. Perusahaan perbankan yang total assetnya terbesar di Indonesia dan tidak pernah delisting dari Bursa Efek Indonesia selama periode 2009 sampai 2013.

3. Perusahaan perbankan yang selalu menyediakan data lengkap mengenai

\section{HASIL DAN PEMBAHASAN}

Data yang dipilih adalah data sekunder. Data sekunder adalah data yang diperoleh dalam bentuk yang sudah jadi, sudah dikumpulkan dan diolah oleh pihak lain, biasanya sudah dalam bentuk publikasi. Data yang telah diperoleh kemudian dihitung dan dianalisis menggunakan loan) or they may consist of goods or services (e.g. consumer credit). Credit encompasses any form of deferred payment”.

CAR, tingkat suku bunga kredit dan penyaluran kredit selama periode pengamatan.

Dari kriteria sampel diatas dapat diperoleh sampel sebanyak 10 perusahaan perbankan.

Teknik pengumpulan data yang dilakukan dalam penelitian ini adalah studi pustaka dan telaah dokumen. Studi pustaka dilakukan dengan mengumpulkan pengetahuan teoritis yang relevan dengan cara membaca dan mempelajari bukubuku, dan jurnal-jurnal yang sesuai dengan topik dalam penelitian ini. Sedangkan telaah dokumen diperoleh dari laporan keuangan tahunan (annual report) perbankan periode 31 Desember 2009 sampai 2013 yang tersedia di Bursa Efek Indonesia (BEI).

komputer melalui software Statistical Package for the Social Science 20 (SPSS 20) dan Microsoft Excel.

Capital Adequacy Ratio (CAR) adalah rasio untuk mengukur permodalan dan cadangan penghapusan dalam menanggung perkreditan, terutama risiko terjadi karena bunga gagal ditagih. CAR 
menunjukkan sejauh mana penurunan aset bank masih dapat ditutup oleh equity bank yang tersedia.

CAR $=$ Modal $x \quad 100 \%$ ATMR
Penulis menyajikan perhitungan Capital Adequacy Ratio (CAR) dari masingmasing perusahaan perbankan adalah sebagai berikut:

Tabel 1

Hasil Perhitungan Capital Adequacy Ratio ( $\mathrm{X}_{1}$ ) Tahun 2009 - 2013

\begin{tabular}{|l|c|c|c|c|c|}
\hline \multirow{2}{*}{\multicolumn{1}{c|}{ Bank }} & \multicolumn{5}{|c|}{ Tahun } \\
\cline { 2 - 6 } & 2009 & 2010 & 2011 & 2012 & 2013 \\
\hline BRI & $13,20 \%$ & $13,76 \%$ & $14,96 \%$ & $16,95 \%$ & $16,99 \%$ \\
\hline BNI & $13,77 \%$ & $18,63 \%$ & $17,63 \%$ & $19,21 \%$ & $17,24 \%$ \\
\hline BTN & $21,75 \%$ & $16,74 \%$ & $15,03 \%$ & $17,69 \%$ & $15,62 \%$ \\
\hline Mandiri & $15,43 \%$ & $13,36 \%$ & $15,34 \%$ & $15,48 \%$ & $14,93 \%$ \\
\hline Cimb Niaga & $13,59 \%$ & $13,24 \%$ & $13,09 \%$ & $15,08 \%$ & $15,38 \%$ \\
\hline Bii & $14,71 \%$ & $12,74 \%$ & $12,03 \%$ & $12,92 \%$ & $12,76 \%$ \\
\hline Danamon & $17,55 \%$ & $13.93 \%$ & $16.62 \%$ & $18,38 \%$ & $17,48 \%$ \\
\hline Panin & $21,53 \%$ & $16,65 \%$ & $17,45 \%$ & $14,67 \%$ & $15,32 \%$ \\
\hline Permata & $12,16 \%$ & $14,05 \%$ & $14,07 \%$ & $15,86 \%$ & $14,28 \%$ \\
\hline BCA & $15,33 \%$ & $13,50 \%$ & $12,75 \%$ & $14,24 \%$ & $15,66 \%$ \\
\hline
\end{tabular}

Sumber: www.idx.co.id, diolah kembali

Berdasarkan data diatas, dapat pengembangan usaha dan mengantisipasi disimpulkan bahwa perbankan dengan potensi kerugian yang diakibatkan oleh Capital Adequacy Ratio (CAR) tertinggi penyaluran kredit. Semakin besar CAR sejak tahun 2009-2013 adalah Bank maka akan semakin besar daya tahan bank Tabungan Negara (Persero) Tbk sebesar 21,75\% terdapat pada tahun 2009. Untuk perbankan dengan Capital Adequacy Ratio (CAR) terendah sejak tahun 20092013 adalah Bank Internasional Indonesia Tbk sebesar 12,03\%terdapat pada tahun 2011.

Semakin tinggi Capital Adequacy Ratio (CAR) maka semakin besar pula sumber daya finansial yang dapat digunakan untuk keperluan yang bersangkutan dalam menghadapi penyusutan nilai harta bank yang timbul karena adanya harta bermasalah. Sedangkang Capital Adequacy Ratio (CAR) bank rendah berarti bank tersebut kurang mampu dalam membiayai kegiatan operasionalnya tersebut.

Suku bunga adalah "Balas jasa yang diberikan oleh bank berdasarkan prinsip konvensional kepada nasabah yang membeli atau menjual produknya. Bunga 
67 AGREGAT: Jurnal Ekonomi dan Bisnis

Vol. 1 No 1 Maret 2017

http://journal.uhamka.ac.id/index.php/agregat

DOI: 10.22236/agregat_vol1/is1pp59-72

juga dapat diartikan sebagai harga yang harus dibayar kepada nasabah (yang memiliki simpanan) dengan harga yang harus dibayar oleh nasabah kepada bank (nasabah yang memperoleh pinjaman).” Tingkat suku bunga kredit merupakan berikut:

Tabel 2

Suku Bunga Kredit $\left(X_{2}\right)$ Tahun 2009 - 2013

\begin{tabular}{|l|c|c|c|c|c|}
\hline \multirow{2}{*}{\multicolumn{1}{c|}{ Bank }} & \multicolumn{5}{|c|}{ Tahun } \\
\cline { 2 - 6 } & 2009 & 2010 & 2011 & 2012 & 2013 \\
\hline fBRI & $16,77 \%$ & $22,76 \%$ & $22,00 \%$ & $16,80 \%$ & $15,95 \%$ \\
\hline BNI & $9,62 \%$ & $36,02 \%$ & $24,01 \%$ & $24,5 \%$ & $26,92 \%$ \\
\hline BTN & $13,31 \%$ & $12,63 \%$ & $12,00 \%$ & $12,25 \%$ & $12,62 \%$ \\
\hline Mandiri & $12,80 \%$ & $12,54 \%$ & $11,99 \%$ & $11,47 \%$ & $11,23 \%$ \\
\hline Cimb Niaga & $13.05 \%$ & $11.72 \%$ & $12.42 \%$ & $12.04 \%$ & $11.68 \%$ \\
\hline Bii & $15,57 \%$ & $12,14 \%$ & $12,90 \%$ & $12,42 \%$ & $11,63 \%$ \\
\hline Danamon & $6,58 \%$ & $5,32 \%$ & $15,72 \%$ & $5,12 \%$ & $15,19 \%$ \\
\hline Panin & $14,50 \%$ & $12,67 \%$ & $11,79 \%$, & $11,26 \%$ & $11,06 \%$ \\
\hline Permata & $12,76 \%$ & $12,67 \%$ & $11,85 \%$ & $10,90 \%$ & $11,86 \%$ \\
\hline BCA & $12,07 \%$ & $10,88 \%$ & $10,35 \%$ & $9,58 \%$ & $9,57 \%$ \\
\hline Sum & & & & \\
\hline
\end{tabular}

\section{Sumber: www.idx.co.id, 2017}

Tabel diatas merupakan data Suku Bunga Kredit pada masing-masing bank selama periode 2009 sampai dengan 2013. Berdasarkan data diatas, dapat disimpulkan bahwa perusahaan perbankan dengan tingkat suku bunga kredit tertinggi sejak tahun 2009-2013 adalah Bank Negara Indonesia (Persero) Tbk sebesar 36,02\% terdapat pada tahun 2010. Untuk perbankan dengan tingkat suku bunga kredit terendah sejak tahun 2009-2013 adalah Danamon Tbk sebesar 5,12\% terdapat pada tahun 2012.

Semakin tinggi tingkat suku bunga

Persentase (\%) tingkat suku bunga ratarata yang ditawarkan setiap pengajuan kredit pada bank. Penulis menyajikan perhitungan Suku Bunga Kredit dari masing-masing perbankan adalah sebagai 
"penyediaan uang atau tagihan yang dapat dipersamakan dengan itu, berdasarkan kesepakatan pinjam-meminjam antara pihak bank dengan pihak lain yang mewajibkan pihak peminjam untuk melunasi hutangnya setekah jangka waktu tertentu dengan pemberian sejumlah

bunga”

Dalam penelitian ini variabel terikat (Y) yang digunakan adalah realisasi jumlah kredit yang disalurkan/diberikan oleh masing-masing bank mulai dari tahun 2009-2013.

Tabel 3

Kredit yang disalukan (Dalam Rupiah) (Y) Tahun 2009 - 2013

\begin{tabular}{|l|c|c|c|c|c|}
\hline \multirow{2}{*}{ Bank } & \multicolumn{5}{|c|}{ Tahun } \\
\cline { 2 - 6 } & 2009 & 2010 & 2011 & 2012 & 2013 \\
\hline BRI & 205.037 .003 & 246.964 .238 & 285.406 .257 & 350.758 .262 & 434.316 .466 \\
\hline BNI & 104.309 .699 & 111.659 .612 & 133.370 .850 & $200,742,305$ & $250,637,843$ \\
\hline BTN & 38.718 .344 & 48.682 .818 & 58.799 .385 & 75.277 .840 & 92.090 .448 \\
\hline Mandiri & 196.488 .172 & 210.123 .448 & 273.623 .240 & 338.629 .096 & 409.855 .249 \\
\hline Cimb & $82,772,139$ & $103,574,635$ & $122,931,369$ & $140,732,390$ & $149,627,573$ \\
\hline Danamon & $58,362,902$ & $73,257,415$ & 85.545 .347 & 90.886 .571 & 103.441 .321 \\
\hline BII & 37.337 .491 & 50.138 .497 & 62.748 .748 & 76.017 .558 & 95.364 .127 \\
\hline Panin & 41.121 .422 & 57.246 .019 & 71.079 .802 & 92.961 .240 & 104.829 .874 \\
\hline Permata & 39.426 .730 & 51.275 .170 & 67.990 .379 & 93.379 .285 & 118.004 .926 \\
\hline BCA & 123.212 .679 & 153.336 .325 & 201.462 .909 & 252.211 .007 & 306.203 .573 \\
\hline
\end{tabular}

Tabel diatas adalah data Kredit yang disalurkan pada masing-masing bank selama periode 2009-2013. Berdasarkan data diatas, dapat disimpulkan bahwa perusahaan perbankan dengan kredit yang disalurkan tertinggi adalah Bank Rakyat Indonesia Tbk sebesar Rp 434.316.466 terdapat pada tahun 2013. Untuk perbankan dengan kredit yang disalurkan terendah adalah Bank Internasional Indonesia Tbk sebesar Rp 37.337.491 terdapat pada tahun 2009.

Hasil penelitian menunjukkan bahwa
Capital Adequacy Ratio (CAR) secara parsial berpengaruh negatif tidak signifikan terhadap jumlah penyaluran kredit. Berdasarkan uji t yang dilakukan pada penelitian ini diperoleh $t_{\text {hitung }}$ sebesar $-0.517<t$ tabel sebesar 1,678, dan memiliki signifikansi angka yang lebih besar dari $0,05(0,608>0,05)$ sehinggga dapat dikatakan bahwa Capital Adequacy Ratio (CAR) berpengaruh negatif tidak signifikan terhadap jumlah penyaluran kredit. Hasil ini sesuai dengan hasil penelitian terdahulu yang dilakukan oleh 
69 AGREGAT: Jurnal Ekonomi dan Bisnis

Vol. 1 No 1 Maret 2017

http://journal.uhamka.ac.id/index.php/agregat

DOI: 10.22236/agregat_vol1/is1pp59-72

Bella Anindita Apsari (2015), M. Zulfikar Aziz (2011) dan Tenrilau (2012) yang menyatakan bahwa Capital Adequacy Ratio (CAR) berpengaruh negatif terhadap penyaluran kredit. Sedangkan hasil ini bertolak belakang dengan penelitian terdahulu yang dilakukan oleh oleh Febry Amithya Yuwono (2012) yang menyatakan bahwa Capital Adequacy Ratio (CAR) berpengaruh positif terhadap penyaluran kredit.

Hasil penelitian menunjukkan bahwa tingkat suku bunga kredit secara parsial berpengaruh positif tidak signifikan terhadap jumlah penyaluran kredit. Berdasarkan uji $t$ yang dilakukan diperoleh $t$ hitung sebesar $1.618<t$ tabel sebesar 1,678 dan memiliki signifikansi angka yang lebih besar dari 0,05 (0.112> 0,05) sehinggga dapat dikatakan bahwa tingkat suku bunga kredit berpengaruh positif tidak siknifikan terhadap jumlah penyaluran kredit. Hasil ini sesuai dengan hasil penelitian terdahulu yang dilakukan saryadi (2013) yang menyatakan bahwa suku bunga kredit berpengaruh positif

\section{SIMPULAN}

Pada penelitian ini penulis meneliti tentang pengaruh Capital Adequacy Ratio (CAR) dan tingkat suku bunga kredit terhadap jumlah penyaluran kredit pada terhadap penyaluran kredit. Sedangkan hasil ini bertolak belakang dengan penelitian terdahulu yang dilakukan oleh Mochamad Syadam Siswantoro (2013), Marsithah Akbar, R.R. dan siti munawaroh (2014), dan Haron O. Moti (2012) yang menyatakan bahwa tingkat suku bunga kredit berpengaruh negatif terhadap Penyaluran kredit.

\subsubsection{Pengaruh Capital Adequacy Ratio} (CAR), dan tingkat suku bunga kredit Secara Simultan terhadap jumlah penyaluran Kredit.

Hasil penelitian menunjukkan bahwa Capital Adequacy Ratio (CAR), dan tingkat suku bunga kredit tidak berpengaruh secara bersama-sama terhadap jumlah penyaluran Kredit. Hal ini ditunjukkan dengan tingkat signifikansi angka yang lebih besar dari $0,05 \quad(0,278>0,05)$, sehingga dapat dikatakan bahwa Capital Adequacy Ratio (CAR), dan tingkat suku bunga kredit Secara Simultan berpengaruh tidak signifikan terhadap jumlah penyaluran Kredit.

perbankan di Bursa Efek Indonesia. Penelitian ini menggambarkan 10 sampel yang telah memenuhi syarat, periode yang digunakan penulis dalam penelitian ini adalah tahun 2009-2013. Berdasarkan 
hasil analisis data dan pembahasan pada bab sebelumnya maka penulis dapat mengemukakan beberapa kesimpulan sebagai berikut: Capital Adequacy Ratio (CAR) secara parsial berpengaruh negatif tidak signifikan terhadap jumlah penyaluran kredit pada perbankan di Bursa Efek Indonesia. Hal ini dapat dilihat dari hasil pehitungan $t$ hitung sebesar $0.517<t$ tabel sebesar 1,678, maka signifikansi $0,608>0,05$. Tingkat suku bunga kredit secara parsial berpengaruh positif tidak signifikan terhadap jumlah

\section{REFERENSI}

Apsari, B.A. (2015). Analisis pengaruh Dana Pihak Ketiga (DPK), Capital Adequacy Ratio (CAR), Non Performing Loans (NPL), Return On Asset (ROA) dan Suku Bunga Bank Indonesia (SBI) terhadap penyaluran kredit perbankan (studi kasus pada bank umum yang terdaftar di Bursa Efek Indonesia Periode 20092013). Jurnal: Universitas Brawijaya.

Brigham dan Houston. (2010). DasarDasar Manajemen Keuangan buku 1 (Edisi 11) Jakarta: Salemba Empat. penyaluran kredit pada perbankan di Bursa Efek Indonesia.

Hal ini dapat dilihat dari hasil pehitungan $t$ hitung sebesar $1.618<t$ tabel sebesar 1,678, maka signifikansi $0.112>$ 0,05. Secara simultan Capital Adequacy Ratio (CAR), dan tingkat suku bunga kredit berpengaruh tidak signifikan terhadap jumlah penyaluran kredit pada perbankan di Bursa Efek Indonesia. Hal ini dapat dilihat dari hasil pehitungan $F$ hitung sebesar 1.318 dengan tingkat signifikansi sebesar 0,278>0,05. . (2011). Fundemental Of Financial Management. Thirtheen Edition. New York: Thomson South Western Mc Graw Hill

Buchs, T. And Mathisen, J. (2005). Competition and Efficiency in Banking: Behavioral Evidence from Ghana. IMF Working Paper WP/05/17, African Department.

Yuwono, F.A. (2012). Analisis pengaruh Dana Pihak Ketiga (DPK), Loan To Deposit Ratio, Capital Adequacy Ratio (CAR), dan Non Performing Loan (NPL), Return On Asset, dan Sertifikat Bank Indonesia Terhadap Penyaluran Kredit Perbankan (Studi Empiris: 
71 AGREGAT: Jurnal Ekonomi dan Bisnis

Vol. 1 No 1 Maret 2017

http://journal.uhamka.ac.id/index.php/agregat

DOI: 10.22236/agregat_vol1/is1pp59-72

bank yang terdaftar di BEI). Tampubolon, P.M. (2013). Manajemen

Skripsi. Semarang: Universitas

Diponegoro.

Haron, O. M. (2012). Effectiveness Of

Credit Management Sytem On

Loan Performance: Empirical

Evidence From Micro Finance

Sector In Kenya Jurnal. Kenya:

University College Kenya

Ghozali, I. (2005). Aplikasi Analisis

Multivariate dengan program SPSS

Semarang: Penerbit Universitas

Diponogoro.

. (2011). Aplikasi Analisis

Multivariate Dengan Program

IBM SPSS 19. Edisi Kelima.

Semarang: Universitas

Diponegoro.

Kasmir. (2008). Analisis Laporan

Keuangan. Jakarta: Rajawali persada.

(2010). Dasar-Dasar

Perbankan. Jakarta: Rajawali persada.

Ketut, R. (2008). Pengantar perbankan dan lembaga keuangan bukan bank (Cetakan ketiga) Jakarta: PT Gramedia

Dendawijaya, L. (2009). Manajemen Perbankan (Edisi Kedua) Jakarta: Ghalia Indonesia. keuangan (Finance Management) (Edisi pertama) Jakarta: Mitra Wacana Media.

Mankiw, N.G. (2005). Principles of Microeconomic, 2nd Edition. South- Westren Publisher Boston.

Marsithah, A.R.R. dan Munawaroh, S. 2014. Analisis pengaruh DPK, Tingkat Suku Bunga Kredit, Non Perfomance (NPL) dan Tingkat Inflasi Terhadap Penyaluran Kredit. Jurnal. Banjarmasin: STIE Indonesia.

Mishkin, F.S. (2004). The economics of money, banking and financial markets, 7th Edition, USA: Person Additison wesley.

(2008). Ekonomi Uang, Perbankan, dan Pasar Keuangan edisi 8. Salemba Empat: Jakarta

Sulhan, M. \& Siswanto, E. (2008). Manajemen Bank: Konvensional \& syariah. Malang: UIN-Malang Press

Siswantoro, M.S. (2013). Pengaruh Dana Pihak Ketiga dan Tingkat Suku Bunga Terhadap Kredit yang Diberikan (studi kasus pada perusahaan perbankan yang terdaftar di Bursa Efek Indonesia). Jurnal. Bandung: Universitas 
Komputer Indonesia.

Mudrajad, K dan Suhardjono. (2011).

Manajemen Perbankan Teori dan

Aplikasi Yogyakarta: BPFE

yogyakarta.

Rimsky, K.J. (2005). Sistem moneter dan Perbankan di Indonesia (cetakan kedua) Jakarta: PT Gramedia.

Saryadi. (2013). Faktor-faktor yang berpengaruh terhadap penyaluran kredit perbankan (Studi pada bank umum devisa). Jurnal: Universitas Diponegoro

Sunariyah. (2004). Pengantar Pengetahuan Pasar Modal. Edisi Keempat. Yogyakarta: UMP AMP YKPN

Sugiyono. (2009). Metode Penelitian Bisnis. Bandung: Alfabeta. . (2010). Metode Penelitian

Kuantitatif Kualitatif \& RND. Bandung: Alfabeta.

Muljono, T.P. 2007. Manajemen Pengkreditan Bagi Bank Komersil (Edisi Keempat) Yoyakarta: Rineka Cipta 